THE EVOLUTION OF THE EUROPEAN REGULATORY FRAMEWORK FOR ELECTRONIC COMMUNICATIONS

Johannes

M. Bauer

2013/41

Johannes M.Bauer

Department of Telecommunication, Information Studies, and Media/

Michigan State University, USA

bauerj@msu.edu 


\section{IBEI WORKING PAPERS \\ TELEFONICA CHAIR SERIES}

2013/41

The Evolution of the European Regulatory Framework

for Electronic Communications.

(C) Johannes M. Bauer

(c) IBEI, de esta edición

Edita: IBEI

Elisabets, 10

08001 Barcelona

Tel. 934121189

Fax. 933040071

E-mail: ibei@ibei.org

URL: www.ibei.org

Depósito legal: B-21.147-2006

ISSN: 1886-2802

Imprime: Ediciones Gráficas Rey, S.L.

Barcelona, December 2013 


\title{
THE EVOLUTION OF THE EUROPEAN REGULATORY FRAMEWORK FOR ELECTRONIC COMMUNICATIONS
}

Johannes M. Bauer

\begin{abstract}
The paper reviews the historical transformation of the European regulatory framework for electronic communications from the era dominated by state-owned enterprises to the presence of regulated competition. In the course of these developments, the vision of the roles of the public and private sectors in electronic communications changed in expected and unexpected ways. While the period is characterized by a shift toward less direct state intervention, the intensity of regulation has increased in many areas. Most recently, in the wake of the financial crisis, new forms of state intervention can be observed, including public investment in communications infrastructure and public-private partnerships. As a result of the reforms, Europe has been able to achieve major successes but it also suffered unanticipated setbacks compared to other regions. The European Union emerged as the global leader in mobile communications during the 1990s and was able to roll-out first-generation broadband access networks more rapidly than many of its peers. Recently, however, Europe as a whole has not performed as well in deploying next-generation networks and advanced mobile communications services. The paper offers a political-economic explanation for these developments and assesses their effects on the performance of the European electronic communications sector and the economy. From this analysis, the European model emerges as a unique institutional arrangement with peculiar advantages and disadvantages. Once these are recognized, sensible next steps to build the strengths while avoiding the weaknesses of the model can be seen more clearly.
\end{abstract}

Keywords: European Union, Regulatory Reform, Broadband, Next-Generation Networks, Investment, Innovation, Adaptive Regulation.

Comments: Paper presented at the IBEI-CEPAL international seminar "Innovación y regulación en las TIC.Una perspectiva comparada entre Europa y América Latina". Barcelona, 30 September - 1 October 2013. 


\section{INTRODUCTION}

During the past decades, Europe has made remarkable progress in transforming its electronic communications sector and improving its performance. For much of the twentieth century Europe overall lagged behind the U.S. in the availability of electronic communication infrastructure, the cost of services, and the innovative dynamics of the sector, especially new forms of data communications and the early Internet. Admittedly, such broad perspectives do incomplete justice to the considerable variance at the subnational level. In Europe, the Nordic countries typically achieved very high performance and in the U.S. considerable regional differences prevailed. Due to a combination of enlightened policy and serendipity, this high-level picture changed quite significantly toward the end of the millennium.

In the 1990s, the European Union (EU) snatched the lead in mobile communications from the U.S. after it adopted a Europe-wide standard (GSM) that allowed overcoming the historical fragmentation of wireless communications. Manufacturers, network operators, and users benefited from economies of scale and unified communications throughout Europe. As a result of the long-term effects of regulatory reforms initiated in the late 1980s, Europe was able to close the gap in broadband access to peer nations. By 2006, the number of broadband access lines per 100 inhabitants in the EU-15 matched the American adoption rate, with several member states boasting better performance than the U.S.

But, somehow surprisingly, this picture changed again as more advanced generations of electronic communications emerged. Europe lost its leadership in wireless communications to South Korea and Japan, who emerged as leaders in mobile Internet technology, typically referred to as third-generation (3G) and later fourth-generation $(4 \mathrm{G})$ mobile. Japan and South Korea also promoted next-generation fixed broadband technology very aggressively and took the global lead in fiber connectivity, seen by many as a critical platform for future digital innovation. In this global change of leadership, the U.S. regained some momentum in the fourth generation of wireless services (4G) and it has improved its position in fixed next-generation infrastructure availability and performance. Again, within this broader development, the observable patterns are rather diverse and varied.

These shifts happened despite ambitious goals and programs developed by the European Union. In the Lisbon Agenda, adopted in 2000, Europe sought to become the "most competitive and the most dynamic knowledge-based economy in the world" by 2010. Although the purpose of defining a shared policy agenda and a framework for the advancement of broadband was achieved, by the time of its midterm review it was apparent that most of the broader goals would not be realized, as many of the fundamental assumptions about the digital economy had changed. Con- 
sequently, the Union in its revised strategy (i2010) refocused on achieving sustainable economic growth and low unemployment by 2010. Many of the earlier goals became embedded in the Digital Agenda for Europe, one of the seven flagship initiatives within the Europe 2020 ten-year growth program. ${ }^{1}$

This paper seeks to explain these observations. Several factors are at work and need to be woven together. Not all of them can effectively be controlled or influenced by national and European policy makers. In that sense they are fully or partially external to the policy system. Among these factors are changes in the global organization of production, the slowdown of economic growth in high-income countries, and the accelerating changes in the technological base of media and communications industries. Other contributing forces are the outcome of earlier policy decisions and the ensuing institutional maturation process. Some of the arrangements implemented since the 1970s seem to have reached the end of their lifecycle and may need further adaptation to changing economic, political, and technological circumstances. In a sense these a self-made constraints, even though there may be considerable inertia and resistance to modifying them. Last but not least, there is an increasing mismatch between the working of the socio-technical system media and communications and the way policy intervention is construed and implemented. We will address these factors throughout the paper.

A closer look at the empirical evidence reveals a much more nuanced and differentiated picture that is not visible when looking at the EU as a whole. There continues to be considerable variance within the member states of the European Union. Both traditional leaders such as the Nordic countries and new member states have achieved outstanding track records, adapting better to changing conditions than others. Often, these are driven by initiatives at the sub-national level, such as public-private partnerships involving municipalities and industry. This suggests that to understand the diversity and complexity of developments in advanced communications, it is necessary to look at multiple levels (local, national, European, global) and their interactions. Moreover, a critical analysis of these developments will benefit from taking broader changes in digital communications and its governance into account. One force is the emergence of the Internet as a unifying platform with a governance model largely built around networks and self-regulation that is quite different from the more hierarchical regulatory model of traditional telecommunications. Another is the need to find frameworks that support additional investment and innovation, two goals that were historically seen as automatic consequences of liberalization and sector reform. While this perspective is not entirely wrong, recent experience suggests that large-scale investment and innovation require complementary institutional arrangements that do not emerge from repeated market interactions alone.

1. See http://ec.europa.eu/digital-agenda/digital-agenda-europe. 
The paper addresses these issues by starting with a succinct overview of the historical path of European communications regulation and policy. It continues with a discussion of the unique features of the European model and its strengths and weaknesses. Section four links technological, economic, and political developments in a co-evolutionary framework that can help shed light on the specific European experience. Lessons for public policy will be drawn in section five before the main points are reiterated in the conclusions.

\section{THE TRANSFORMATION FROM STATE OWN- ERSHIP TO REGULATED COMPETITION}

The history of European electronic communications reform has been told many times so that it is not necessary to recap it in detail (Belloc, Nicita, \& Parcu, 2013; de Streel, 2008; Eliassen \& Sjovaag, 1999; Michalis, 2006; Noam, 1992; Thatcher, 2002). Nonetheless, it may be helpful to highlight a few main aspects as they contribute to a fuller understanding of the recent developments. For much of the twentieth century, European electronic communications was organized around state-owned posts, telephone, and telegraph service providers (PTTs. However, a broad variety of approaches existed within this broader organizational framework (Foreman-Peck \& Müller, 1988; Noam, 1992). Whereas in most countries national state-owned monopolies prevailed, in very few cases the main network operators were jointly owned by public and private owners (e.g., Italy. In some countries the sector was organized along services (e.g., Italy, where local, long distance, and satellite services were provided by separate entities) and in others by regions (e.g., Finland, where more than 50 municipal network operators were integrated by a national company. Moreover, interactions between network operators and equipment manufacturers differed, although there was a recurring pattern of close collaboration between the national electronics industry and service providers.

These arrangements started to destabilize beginning in the 1970s due to the confluence of intellectual, political, technical, economic, and social developments. Among intellectuals and practitioners new views of the main drivers of economic growth and prosperity were discussed that attributed central importance to information and communications technology (ICT) (Bell, 1973; Toffler, 1980). Among European decision-makers, a view took hold that the continent was falling behind peer nations in these critical technologies (Nora \& Minc, 1978). At the same time, traditional policies of state intervention in the economy that had served many nations well in the post-World War II period were not able to prevent a period of stagflation (a combination of stagnation and inflation. Consequently, trust in the ability of government to steer the economy was fading and new political forces advocating a smaller role of 
government in the economy gained ground worldwide. Given poor macroeconomic performance, public finances were strained and limited allocation of public funds to large-scale network infrastructure projects at a time when the ICT sector needed massive investment in infrastructure. Slowly, a new blueprint based on liberalized markets, reduced state ownership, and independent regulation was accepted as a superior solution. Such sector organization was widely deemed as one of the reasons why the U.S. communications industry was more innovative and dynamic than its European counterparts. A third component were technological and economic changes that created demand-side and supply-side pressure for reform. Large users were eager to take advantage of new forms of data communications but the prevailing monopolistic structures were slow in introducing innovations and in responding to their needs. Major supplier industries also were seeking economies of scale that could not be realized in national markets any longer.

Taken together, these forces created policy disequilibrium and an opportunity to change the status quo. Reforms started at the level of individual nation states, with Sweden and the U.K. among the pioneers. More sweeping changes were initiated when the European Commission (EC) became a promoter of sector reform in the 1980s. Acting somewhat removed from national coalitions of interest, policy-makers in Brussels developed a vision, expressed in the Green Paper on Telecommunications, of a pan-European electronic communications sector that would overcome the "patchwork Europe" and launch the European ICT sector as well as the European economy into a new age of prosperity. As in the American reform process, the momentum generated at a higher level in the policy system was critical to get the reform process moving and forge consensus visions that could be implemented. In a series of directives, the European Commission (EC) proceeded to introduce measures that successively liberalized terminal equipment, value-added and other services, until eventually, in 1998 all services and networks were opened to competition (Bance, 2007; Belloc et al., 2013; M. E. Cave \& Valletti, 2000; Jordana, 2002; Thatcher, 1999). The EU realized in a little more than a decade a program that had taken the U.S. nearly four decades to develop and implement, not a small feat. As part of the transformation, new independent national regulatory authorities (NRAs) were to be established. However, no consensus could be found to establish a European regulatory agency. Coordination at that level was orchestrated among national regulators, initially in the European Regulators Group (ERG) and now in the Body of European Regulators of Electronic Communications (BEREC. Given the sensitivity of the issue, the Commission did not issue any directive requiring privatization of the network operator, although each incumbent had to succumb to the new regulatory regime. Most EU member states adopted policies of privatization, but more or less significant public stakes in the incumbent were retained. In 2012, Luxembourg was the only member stat that had retained full state ownership in Entreprise des Postes et Télécommunication, whereas seven member states, including Spain, Italy, and the Netherlands, had sold all shares to private owners. However, in some case, such as the Netherlands, the public sector kept a golden share that could veto 
important management decisions. This led to the paradoxical situation that fully or partially state-owned operators became subject to state regulation, an institutional model with many potential conflicts of interest and incentive problems (Bauer, 2005; Edwards \& Waverman, 2006).

The reforms implemented interacted with technological, economic, and political forces to generate a virtuous cycle of investment, increased competition, price declines, and accelerated adoption. During much of the twentieth century, the EU trailed the US in terms of fixed lines per 100 inhabitants. Given the rapid expansion of mobile communications in the EU, by 1997 the EU-15 could boast more access paths (fixed and mobile access lines) per 100 inhabitants than the US and by 2002 the EU-28 surpassed the US. ${ }^{2}$ In fixed wired broadband access lines, a similar picture of a narrowing gap is observable for the EU-15 region. Although the broadband trajectory of the two regions is more similar than in voice access lines, the US led the EU-15 until 2006, when the EU surpassed the EU-15 region. Because of the lower income

Figure 1: Access paths (fixed and mobile access lines) per 100 inhabitants 1970-2010.

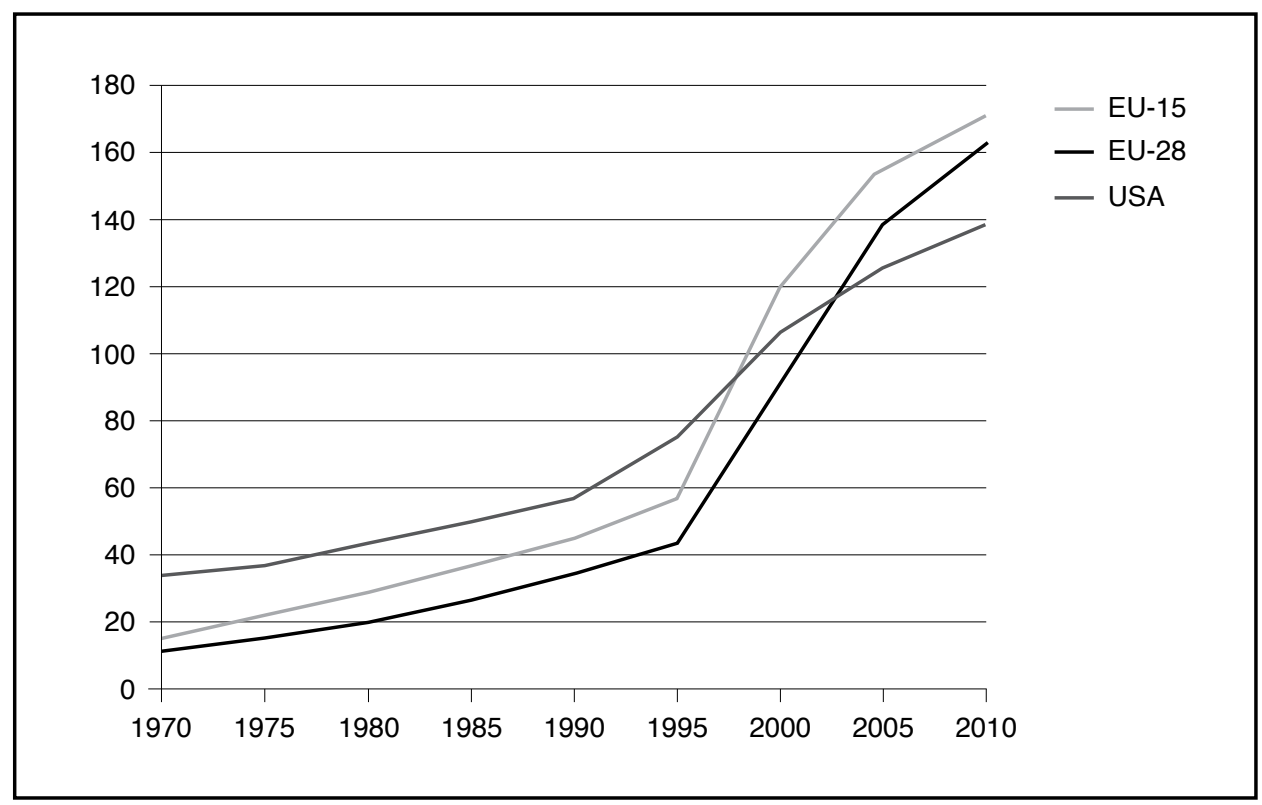

Source: ITU World Telecommunications Indicator Database

2. A note of caution is in order, as European data count SIM cards and not necessarily subscribers. Due to the prevalence of multiple SIM cards, EU data likely overstate the diffusion of mobile service. 
Figure 2: Fixed (wired) broadband access lines per 100 inhabitants 1998-2010.

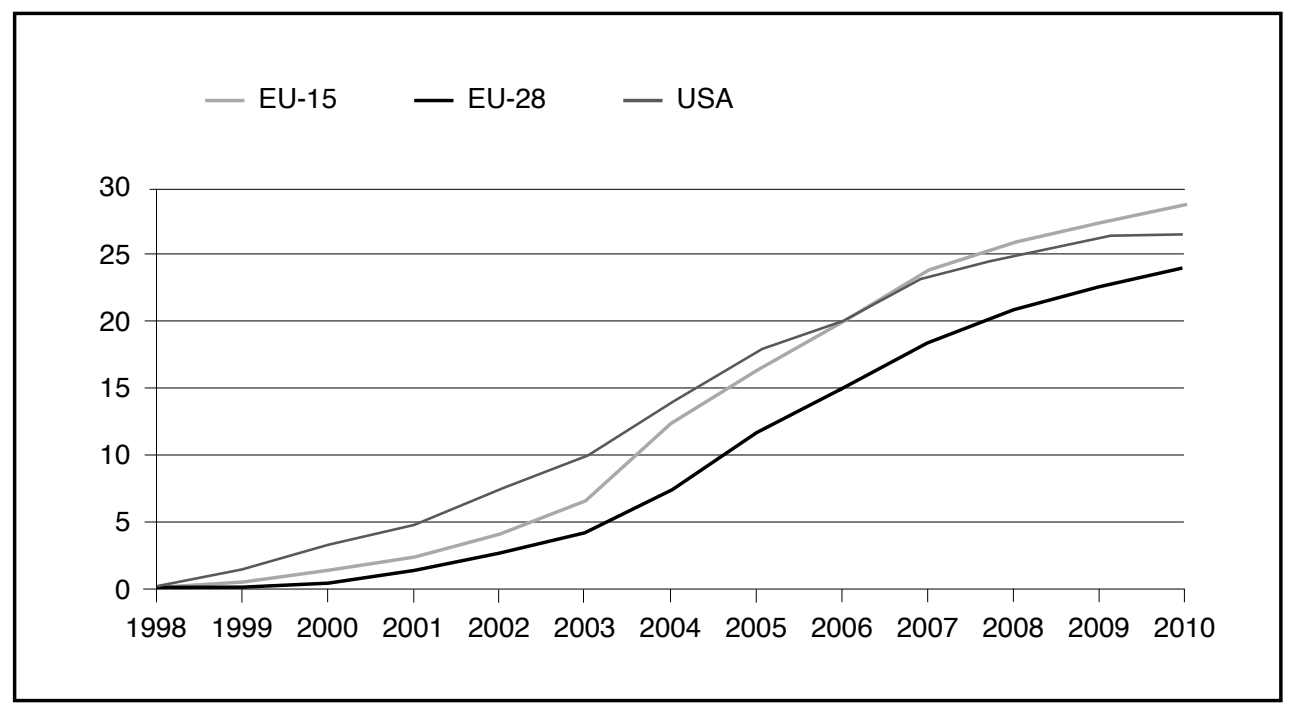

Source: ITU World Telecommunications Indicator Database

and different political and regulatory conditions in the new member states, the picture differs with regard to the EU-28, which continues to lag behind the US, despite an overall similar adoption pattern. ${ }^{3}$ Finally, in a cross-national comparison, several European member states had reached higher broadband adoption by $2010 .^{4}$

3. Again, great caution is in order when comparing numbers across countries and regions. Fixed broadband is typically subscribed by households or firms and not on an individual basis. In as far as there is variation in household sizes, a comparison of per capita values is biased (Bennett, Stewart, \& Atkinson, 2013; Wallsten, 2008)

4. However, this picture also would change dramatically if one were to look at US states rather than the US. If a comparison were performed at that level of granularity, several US states, including the District of Columbia, New Jersey, Connecticut, and Massachusetts would be among the top ten. In 2008, seven of the top ten performers were US states and three EU member states (Bauer, 2008). 
Figure 3: Broadband adoption in the EU-15 and the US 2010.

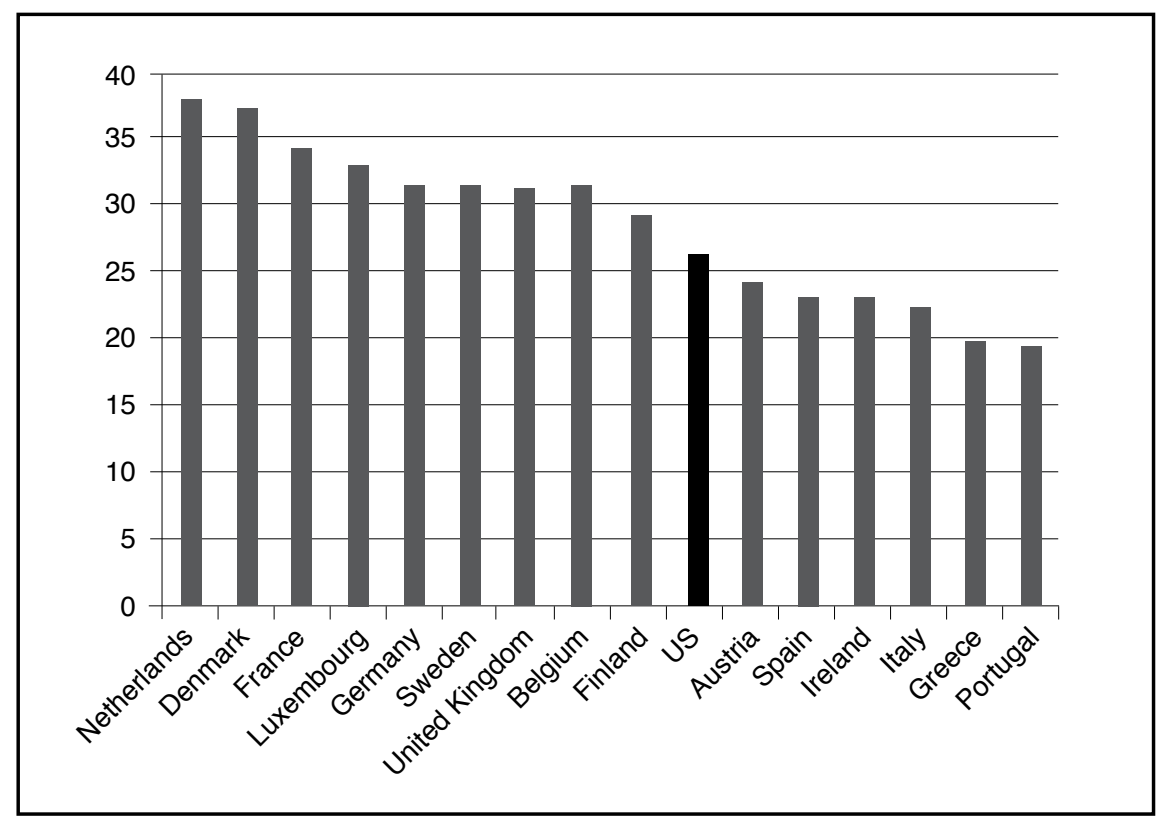

Source: ITU World Telecommunications Indicator Database

The overall regulatory framework was periodically reviewed for its consistency and compatibility with the state of technology and uses. A first major overhaul took place in 2003 and another one in 2007. In the most recent review, the realm of regulation was reduced to fewer submarkets, although the intensity of the remaining regulations gradually increased across most of Europe (Zenhäusern \& Schneider, 2012; Zenhäusern, Schneider, Berner, \& Vaterlaus, 2012). These reforms unleashed efficiency gains and a new dynamic in the European telecommunications industry, particularly during the early years of restructuring.

Prices declined rapidly, the variety and diversity of equipment and services increased greatly, and the adoption of services was boosted. Users started to bypass the fixed network, relying increasingly on mobile services. In the business market segments, new service providers started to offer a broadening array of options. Moreover, during the late 1990s the European approach with its stronger role for government became a blueprint for many middle and low-income countries. Nonetheless, the luster of the European model started to fade away in the past few years. A key problem of many countries and of the EU overall is that the policy approach was more successful in squeezing efficiencies out of the existing system than to stimulate the transition to the next generation of infrastructures and services, which require considerable investment in infrastructure. This is not equally important across all of Europe, as several nations, including Sweden, Denmark, and the Netherlands, managed to overcome this challenge with innovative policies and public-private sec- 
tor cooperation. Nonetheless, the lack of network investment is a serious problem to which currently no clear solution is in sight. The EU has sought to address these challenges in a series of recent policy documents, including the recommendations for next-generation networks (M. E. Cave \& Shortall, 2011; EC, 2010). At the same time, the Union announced cutting subsidies for broadband networks as part of fiscal austerity measures, thus sending mixed signals to the market participants.

\section{UNIQUE ATTRIBUTES OF THE EUROPEAN MODEL}

Compared to other parts of the world, the European model has several unique attributes that help explain its overall dynamics. Among the notable features of the European approach are:

- An opportunity to design regulatory institutions, building on the historical experience elsewhere.

- A stronger integration of regulation with principles of competition law and economics.

- A framework conducive to the fusion and further integration of media and information industries.

- An openness to realize synergies between the public and the private sector.

- Continued economic, political, and cultural heterogeneity.

- A relatively weak presence in computing and other key technologies.

We will discuss these aspects briefly in the following subsections.

\subsection{An Opportunity for Informed Institutional Innovation}

Opportunities to design and implement a new framework for entire industries in a more radical fashion arise infrequently in history. There is considerable evidence that institutional change follows a pattern in which periods of gradual adaptation are punctuated by periods of more rapid change. Such windows of opportunity arise if problem pressure has built up and a sufficient number of stakeholders share a vision of an alternative set of policies so that change is feasible and not blocked by veto players (Baumgartner \& Jones, 1993; Tsebelis, 2002). In Europe, the perception that the historical monopoly organization of the sector was not well suited to the new technological opportunities was growing in the 1970s. The report by Nora and Minc 
(1978) to French President Valery Giscard d'Estaing, which carefully documented the increasing importance of the integration of telecommunications and computing (termed "telematics") was widely read and solidified the notion that Europe was lagging behind its competitors in global markets. The authors proposed new national policies to harness the innovative power of telematics, a perspective that influenced important research and development programs initiated at the national level and early European programs launched by Brussels, including the European Strategic Programme for Research in Information Technologies (ESPRIT), the R\&D in Advanced Communications Technologies for Europe (RACE), and many more initiatives (see the detailed discussion in Ungerer, 1988).

However, gradually the architects of free and open markets prevailed and by the time the Green Paper on Telecommunications was released the policy blueprint had changed to a model embracing liberalization with industrial policy as a complementary form of public intervention (EC, 1987). A key problem was seen in the fragmentation of the European information industries into national markets, technological standards, and business models (what was later termed the "Cost of Non-Europe". Given the long history of monopolistic sector organization, it was clear that any transformation would take considerable time and effort and could only be achieved with the help of independent oversight (Jordana, 2002; Majone, 1996a, 2001, 1996b). The only institutional alternative available to the public enterprise model was independent regulation by a government or government-licensed body, as had been the case in North America since the late nineteenth century. At the time Europe considered liberalization, the North American regulatory model, which had evolved over many decades, was under attack by multiple stakeholders as overly bureaucratic and captured by special interest groups (Becker, 1983; Owen \& Braeutigam, 1978; Peltzman, 1976; Stigler, 1971), a discussion that can be traced back to the 1940s (Phillips, 1993). Eventually, beginning in the 1950s, a very slow and incremental process of regulatory reform and deregulation had been set into motion by courts, regulatory agencies, and legislators and had resulted in numerous deregulatory and re-regulatory measures.

This experience could be taken into account when European policy-makers, advised by consultants and scholars, worked out a new sector model (Bauer, 2010a; Majone, 1991; Vogelsang, 2003). The U.S. model of regulation could not easily be implemented in the statutory legal systems of continental Europe but eventually solutions were devised, often leading to the creation of special private sector bodies. Europe faced other constraints that shaped the outcome of the regulatory setup. Member states were not willing to delegate regulatory powers over industries seen as crucial for their prosperity and political systems to a European agency, resulting in a decentralized system of now 28 national regulators coordinated by directives and other policy measures from Brussels. Over time, informal mechanisms of coordination between the national regulatory agencies (NRAs) emerged. 
During the early years, there was also a shortfall of experts trained in regulation. Consequently, the early regulatory bodies were small and followed pragmatic, streamlined procedures. However, as agencies matured this changed as the novel agencies evolved in a life-cycle that was not unlike that which had plagued their North American counterparts (Goldberg, 1976): the number of stakeholders with potentially conflicting interests increased with the opening of markets to new entrants, the number of experts in consulting, law firms, and interest associations expanded, and the regulatory issues became more complicated. Whereas regulation initially was a force for change, it increasingly became bogged down by bureaucracy, intervention into detail and intractable conflicts of interest. As in other countries, such processes of calcification can be counteracted by regulatory reform, which is currently considered all across Europe.

\subsection{An Integrated and Overarching Framework}

A second important difference of the European approach relates to the conceptual foundations used in addressing regulatory problems. European telecommunications policy had been informed by normative models of the role of the state in the economy. Telecommunications service providers were in most countries among the largest employers and investors and hence provided government leverage to pursue economic goals (Nowotny, 1982). State actions were informed by two largely incompatible conceptual frameworks: on the one hand a pragmatic theory of the social economy that envisioned public enterprises as instruments of public policy (Thiemeyer, 1983). This approach had many similarities to the early institutional economic that informed and shaped early public utility regulation in North America (Bauer, 2003). On the other hand, public enterprise management was informed by the neoclassical theory of optimal public enterprise decisions (Bös, 1981). This approach was closely related to the neoclassical theory or optimal regulation, which was the dominant paradigm in North American regulation when Europe redesigned its approach. In contrast to the earlier vision of regulation, neoclassical theory narrowly construed regulation as a response to market failure, most importantly to market power, externalities, and public goods (Berg \& Tschirhart, 1988; Laffont \& Tirole, 2000; Spulber, 1989; Train, 1991). Moreover, like the older approach it used a static equilibrium model to design optimal intervention. As this approach was seen as the best practice of regulation both by practitioners and academics, European regulation widely adopted it. However, the European approach deviated in one important aspect from its North American counterpart by integrating sector regulation with principles of competition law and antitrust economics (Marcus, 2003).

Only market segments in which competition is deemed to be insufficient can be subject to ex ante regulation. Over time, elaborate joint processes emerged, 
involving NRAs and the European Commission, to test for the presence of significant market power (SMP), either by a single firm or by several firms jointly (de Streel, 2003, 2008; EC, 2002; Kiessling \& Blondeel, 1998). Both actual market structure and market entry conditions are part of the test. This approach resulted in a framework whereby relevant markets had to be defined in a collaborative process but it also allowed responding to national and even local conditions. In 2003, 18 retail and wholesale markets had been identified in which ex ante regulation was seen as appropriate because of the prevalence of significant market power (EC, 2003). In its 2007 review, the Commission reduced the number of relevant markets to seven, one retail and six wholesale markets (EC, 2007; Tintor, Jankovic, \& Milicevic, 2010). The tacit conceptual framework underlying this approach is that competition is superior to regulation and that regulation is a stopgap to avoid the abuse of market power. This is a far-cry from the model that had prevailed before, which saw collaboration between the public and the private sector as an integral part of overcoming the challenges of infrastructure provision at an affordable level and in a ubiquitous manner across space and demographics. This alignment between antitrust and regulation resulted in a more coherent and elegant approach. In practice, the outcomes are roughly comparable to the policies adopted in the more complicated U.S. system (Marcus, 2003, 2005). However, the model ran into difficulties of another kind. Regulatory practices were refined in a context of opening existing networks to competitors. The static economic equilibrium approach was a sufficiently accurate approximation to address these issues. However, it started to backfire when the problem situation shifted to needing to find a new dynamic balance between investment, innovation, and the goal of supporting new entrants and new incumbent players.

Another aspect of the integrated approach pursued in Europe is the explicit attention paid to convergence of media and telecommunication market segments (EC, 1997). The notion of convergence is a much stronger guiding vision for policy in Europe and in Asia than in the U.S., where a broader view prevails that recognizes that there are several other trajectories of change (e.g., divergence, differentiation, fusion. The EU made a concerted effort to design a framework that is most conducive to these transformational forms of innovation. Although a full discussion would exceed the scope of this paper, it should be mentioned that the principles of technological neutrality, competitive neutrality, and provider neutrality that underpin European policy ease many boundary conflicts that continue to affect the American policy discourse. Moreover, the potential for innovation embedded in a converged media sector is inspiring a main thrust within the Digital Agenda 2020 (EC, 2013).

\subsection{The State as a Contributor Rather than a Mere Stopgap}

A third aspect of the European model is the continued belief that the public sector can fulfill important roles by intervening in a more discretionary fashion via 
taxes, subsidies, and public procurement. This is met with a high degree of skepticism by some players in Europe and across the Atlantic. However, the effects of institutional arrangements on performance are more complicated than often assumed and the capability of the public sector to intervene successfully in high-technology industries varies considerably across nations. This implies that the interaction between public and private players can unfold in many different ways with examples of success and failure not necessarily allowing straightforward identification of best practice models (Bauer, 2013; Belloc, Nicita, \& Rossi, 2012). The EU has a long track record of industrial policy programs even though their effects are often disputed. Some of the large-scale recent initiatives in ICT, such as the Lisbon Agenda and i2010 have had rather disappointing overall outcomes. However, in such an assessment one has to keep in mind that the overall economic conditions changed greatly rendering an evaluation of the program nearly impossible.

In theory, a public sector organization could be a vehicle to internalize types of market failure that are not directly related to market power, such as the widespread spillover effects of advanced information infrastructure many of which constitute externalities or have public good character (Frischmann, 2012). This was one of the rationales of public enterprises to begin with although the practical implementation often fell short of the vision. In the new environment based on a competitive market vision, there are potential tensions between these forms of state intervention and the goal of safeguarding a level competitive playing field. The European Commission has sought to address this tension with its state aid policy although this often results in constraints that may prevent the design of effective policies (Gomez-Barroso \& Feijoo, 2012). The willingness to experiment with innovative partnerships has, to some degree, helped overcome the deficiencies in market-driven network infrastructure investment that has been plaguing Europe as a result of policies that failed to explicitly consider investment effects of regulation (Falch \& Henten, 2010; Serentschy, 2013). In countries where such experiments are widespread such as Sweden, Denmark, and the Netherlands, broadband deployment and investment in advanced network infrastructure has been robust. While these pragmatic models seem to work in small high-income countries, it is doubtful whether they can easily be migrated to other nations.

There is another interesting aspect to this continued willingness to use the ability of the public sector to intervene in ways that are different from other agents that might provide an advantage to Europe in critical areas of innovation. Much of the recent discussion has focused on the app economy with its very high innovation dynamics (West \& Mace, 2010). However, innovation in the ICT ecosystem takes place in different forms and processes. Some are facilitated by open network architectures and competition but others require coordination among large numbers of stakeholders. Such coupled innovations are often risky and their benefits occur in the form of public or club goods. Consequently, in a market-driven environment 
they may not happen unless an actor is willing to facilitate coordination among the players. Examples of such types of innovation are mobile Internet services and largescale systems such as electronic health cards. The case of the mobile Internet illustrates that the requisite coordination functions can be assumed by private industry (e.g., NTT DoCoMo in Japan, SK Telecom in South Korea, and with great delay Apple in the US) but in the case of health IT thus far no such blueprint for coordination has emerged. Only countries where government has convened and orchestrated the relevant stakeholders, including the medical profession, insurance companies, the pharmaceutical industry, has the technology taken off (e.g., in Germany, Switzerland. From this vantage point, the European cultural and political framework may position the region well for important systemic innovations that have the potential to greatly transform how we live and work.

\subsection{Challenges and Advantages of Cultural, Political and Economic Het- erogeneity}

A fourth aspect is the continued economic, political, and cultural heterogeneity across Europe. While overcoming it was one of the stated goals of European economic and political integration, some degree of diversity is not necessarily negative. A key question therefore is how integration and differentiation can and should be balanced. That diversity can be advantageous is often overlooked or poorly understood. It appears in a rather different light once seen in the context of governing the dynamic development and complexity of the information and communication system. Evolutionary strands of innovation theory have pointed out for some time that invention and innovation typically are new combinations and re-combinations of existing technological, economic, or organizational knowledge. Innovation and investment decisions, which in the technologically dynamic ICT system are closely related, take place under uncertainty. At the time an innovation decision is made (a new combination is tried out), it is usually not known whether it will be accepted by users and succeed in the marketplace. If different innovators explore different re-combinations, the chances that one or more will succeed are increased. This was already pointed out by Hayek in his metaphor of competition (in the sense of rivalry among firms) as a "discovery procedure" (of both things that work and those that do not) (Hayek, 1968, 2002). One could argue that in a complex adaptive system with many interdependencies and non-linear interactions conditions for success are further complicated and the value of experimentation enhanced.

A similar argument can be made for policy diversity and institutional diversity. In a dynamic, complex adaptive system such as ICT, policy interventions also take place under a considerable degree of uncertainty. Although this is rarely admitted by decision-makers for fear that it would undermine the decisiveness and ability to steer the system, many policies are "real world experiments" whose outcomes are not known with certainty. This insight has led Bunge (1979) to caution against large- 
scale systemic interventions and to point out the advantages of controlled, more local experiments that can help learning about the consequences of new policies. Institutional diversity and local differences can help improve our understanding of the potential effects of policies and in sorting out measures and combinations of measures that work from those that do not. If initially used locally or at a national level, others can learn and adapt their policies and institutional arrangements accordingly. Often, this will be a process of amalgamation and adaption rather than direct copying (Bauer, 2010a). Scholars in political science and law have similarly recognized that local experimentation can be helpful. Teske $(1990,1995)$ has studied the benefits of the decentralized, two-tier structure of the U.S. system of regulation. States serve as laboratories for policies that serve to inspire others and, in some case that prove to be clearly successful, are synchronized and coordinated by federal agencies to be implemented nation-wide. In a similar vein, Cherry (2007) has pointed out that federal agencies or policy coordinators can serve as a "patching mechanism" that can help overcome a collective action problem of reaching superior policies that are beyond the reach of local adaptations. Most recently, Sabel \& Zeitlin (2010) analyzed the "experimentalist" nature of the European governance approach, identifying the interaction between member states and the European-level organizations as a system that facilitated policy learning and adaptation.

\subsection{Presence and Experience in Key Technologies}

A final, fifth, point that deserves mentioning is the relatively weak presence of European firms in key technologies that are powering advanced communications. Several waves of technological change have contributed to a closer integration and fusion between computing, media, and communication industries. During the 1960s, new combinations of computing and telecommunications functions spawned innovations in data communications, telematics services, and the emergence of a new communications architecture and platform, the Internet. Subsequently, advances in signal representation and processing enabled digital audio and video and the diffusion of fixed and mobile broadband networks in combination with new network architectures (e.g., content delivery networks, cloud computing) further expanded the space of innovation opportunities. Referring to the integration of telematics and media, some authors referred to the converging world of media and telecommunications as "mediamatics" (Latzer, 1997). While widely used, the term convergence obfuscates the various developments that unfold: the technological integration driven by digitization, advances in computing, and broadband networking and the parallel differentiation and fragmentation into numerous new services and applications (Greenstein \& Khanna, 1997). 
The more complicated value net of advanced communication services resembles the value net of computing services. Modularity, layering and plasticity of the technological base create unique conditions for success. European firms do not hold a strong position in these areas so that much of the momentum is now located in the U.S. and in Asia, which has quickly caught up to America (Falch, Henten, \& Vandrup, 2010). At the same time, once leading European technology firms such as Nokia, have fallen way behind their international competitors.

\section{GOVERNING THE SOCIO TECHNICAL SYS- TEM ICT}

Before we can attempt a comprehensive explanation of the patterns reported in section two, a deeper look at the fundamental challenges of governing a dynamic socio technical system such as ICT is required. The overall conditions of high performance in electronic communications have changed quite substantially since the era of monopoly provision. We will argue in this section that the intellectual and practical foundations of regulation have not fully made this transition, leaving a potential mismatch between the working of the system to be governed and the design and implementation of governance (Bauer, 2013). Particularly three areas need to be reconsidered. First, regulation would benefit from taking innovation explicitly into account. Second, interdependencies among players need to be better understood. Third, new initiatives to overcome the inertia and shortcomings of the existing regulatory system, to adapt policy to changing circumstances, are needed. This includes a higher awareness of the costs and benefits of regulation.

A first deficit of prevailing regulatory approaches is that they continue to be rooted in a static model of the sectors they seek to address. Over the past three decades, regulatory practices have been designed and refined to address problems of market failure and deficiencies in response to national or regional contexts. The institutional and regulatory reforms put in place since the 1980s have helped unleash and accelerate the innovative power of digital technology (Cowhey \& Aronson, 2009; OECD, 2011). However, innovation was seen as a desirable byproduct of increased competition rather than a direct objective that should inform the design of regulation. Hence, the legacy of static monopoly regulation continues to reverberate in core aspects, such as the focus on separating monopolistic and competitive market segments or the determination of regulated prices based on long-run incremental costs. Future-oriented ICT policy will need to overcome this shortcoming and be based explicitly in a dynamic theory of innovation and investment. 
A focus on investment and innovation requires a new look at the conditions of innovation in the ICT system. From an economic point of view, investment and innovation decisions are very similar in that both are decisions under uncertainty and both require upfront commitment of resources. In the advanced ICT system, innovation primarily happens in specific areas and locations of the system, with the innovation trajectory of the entire system emerging from these decentralized decisions. Examples of such innovation loci are components (semiconductors, lasers, optical fiber) and devices (terminals, routers, servers), assembled and interconnected in local, regional and global networks. On these networks innovation happens in applications (email, P2P, browsers) and services (voice, messaging, search, financial transactions. There are many interdependencies between these forms of innovation. For example, the technical characteristics of the network enable and constrain the types of applications and services that can be offered. Within this ecosystem, the locus of innovation activity has shifted tremendously in response to market reforms (Fransman, 2002, 2007, 2010). Whereas historically network operators were heavily involved in research and development $(R \& D)$, these activities have migrated to component manufacturers (e.g., Cisco, Intel, Huawei, Nokia), device manufacturers (e.g., Apple, Samsung), and technology companies offering applications and services (e.g., Google, Facebook, Apple, Microsoft, IBM.

Innovation thrives in economic environments that reward risk-taking with (temporary) super-normal profits. In most industries, but mediated by the economic and technological peculiarities of a sector, innovation is most vigorous under conditions of strong rivalry among competitors. Both too little rivalry (i.e., high market concentration) and too much rivalry have negative consequences for the incentive to innovate (Aghion, Bloom, Blundell, Griffith, \& Howitt, 2005). Given its origins in static equilibrium economics (e.g., the goal to set a price achieved in a perfectly competitive market), regulatory theory and practice does not pay sufficient attention to innovation. This shortcoming is most apparent in policies governing access to network elements (e.g., local loops) but also implicit in the recent move toward geographically differentiated regulation. In both cases it is not the policy per se but often the specific pricing of regulated elements. Increasing awareness of the bias generated by long-run incremental cost pricing (LRIC) and its variations has resulted in new approaches, such as risk-based contracts and network sharing arrangements. Whereas these are moves in the right direction, they replace regulatory intervention for marketplace innovation, often creating incentives for stakeholders to coopt government agencies as part of their competitive strategies. Moreover, they do not go far enough to take the systemic nature of innovation into account (we will come back to this point at the end of this section.

A second area in which current regulatory theory and practice fall short of the new reality of ICT markets is the incomplete consideration of the increasing intercon- 
nectedness and interrelatedness of players in the advanced communications system. During the age of monopoly regulation (and public monopolies respectively), policy makers were able to influence the key aspects of sector performance. In the new open market environment, where some of the activities are subject to regulation but many others are not, the control span of policy is reduced. Not only can policy not control all relevant aspects of the sector, the effects of regulation are also influenced and possibly undermined by firm strategies outside the regulated realm. Consequently, good policy needs to take its effects on both regulated and unregulated stakeholders as well as any feedbacks into account. Some interdependencies among participants in the ICT ecosystem are organized and internalized in market transactions but others are true externalities and public goods. Aspects of this are recognized in a lively literature on platform markets. Going back to early attempts beginning in the 1970s, the economic literature on multi-side markets greatly expanded in the past fifteen years. Although definitions vary, platforms are generally seen as firms that enable transactions among third parties. Parts of the literature focus on the role of technical platforms as enablers of complementary technologies and services (Gawer \& Cusumano, 2002) while others emphasize the role of platforms to help reduce transaction costs and internalize externalities and thus reducing barriers to economic transactions (Armstrong, 2006; Evans, 2012; Hagiu \& Wright, 2011; Rochet \& Tirole, 2003; Rysman, 2009; Spulber, 2006). A recurring conclusion from this literature is that the design of public policy needs to look at the entire web of economic relations and not just one side of a market to avoid erroneous decisions (Bauer, 2013). Hence, when diagnosing market power and setting prices, a broader analysis than is currently performed is required. Some of these insights have been adapted in efforts to design better regulatory policies (Ballon \& Heesvelde, 2011; Claffy \& Clark, 2013).

The research on platform markets allows designing better regulatory approaches but in some ways it does not go far enough. For one, it does not take spillover effects into account that are not reflected in market transactions. There is evidence that such public and quasi-public good effects are pervasive (Frischmann, 2012; Greenstein, 2011; Hogendorn, 2012). Moreover, in the ICT system, regulatory interventions typically affect players in differential ways, leading to cascading positive and negative feedback effects. At a very abstract level, new tools emerging from network science have started to pay direct attention to such forms of interdependencies among players (Easley \& Kleinberg, 2010). Several authors also have suggested that notions from innovation economics or the theory of complex adaptive systems can help provide an appropriate framework (Atkinson \& Ezell, 2012; Cherry, 2007; Whitt \& Schultze, 2009). Although some of these concepts enjoy increasing traction, they have not yet been employed to develop a systematic instrumental theory of network governance in which the potential direct and indirect effects of intervention are systematically examined and taken into account. However, there is a growing literature that is aware of potentially contradictory effects and the need to examine the net effects of policy at an aggregate level (Bauer, 2010b; Bourreau, Cambini, \& Hoernig, 2012; Cambini \& Silvestri, 2012). Because these net effects are dependent on 
the local and regional context, one policy may not be the best solution across a larger region such as the EU or the US. Geographically differentiated approaches may be better able to respond to these contextual factors (Belloc et al., 2012).

This leads to a third challenge of governing dynamic socio technical systems: the need to adapt forms and instruments of governance in response to system states. Such adaptation is needed because the effects of interventions on the performance of dynamic systems are typically not known with certainty. Often, they occur in the form of emergent properties that can only be observed ex post. Good regulation therefore has to monitor the important state variables and change in response to the observed states (Cherry \& Bauer, 2004). Compared to legislation, regulation is a more adaptive institutional approach to governance. Nonetheless, over time, regulation like many other institutions is prone to red tape and other forms of rigidity. This may include organizational routines that cannot be changed easily, a growing body of case law and precedent that constrains subsequent decisions and may be difficult to overrule, experts trained in a certain way, and stakeholders who benefit from maintaining the status quo. The European model seeks to mitigate these effects with periodic reviews of the overall approach but it is not immune to all of these effects. One could hypothesize that problems related to rigidity increase with the age of the regulatory system, as more stakeholders participate, their positions become more difficult to reconcile, and the initial drive of a regulatory agency to contribute to the public good may give way to more routinized behavior and loss of vigor (Melody, 2013). However, even though regulation may experience a life cycle, it is possible to rejuvenate agencies and adapt, as demonstrated in countries that have changed the organizational setup of regulation (e.g., the UK) or streamlined practices (Goldberg, 1976; Martimort, 1999).

Such periodic transformations might be facilitated if the widespread (often tacit) assumption that regulation is costless and efficient were abandoned. One could look at this working assumption as a modern version of the "public interest" theory of regulation or the related notion that regulation is intended to increase welfare, a more narrowly construed economic criterion (Bozeman, 2007; Joskow \& Noll, 1981; Kahn, 1970/71). The notion that regulation is mainly designed with such goals in mind has been widely challenged by political-economic theories of regulation since the 1940s (Wilson, 1980). As a theoretical abstraction, the assumption of costless regulation to enhance welfare may be justifiable. However, it becomes a problem when policy recommendations are directly derived from a formal model based on the premise. A pragmatic and practical theory of regulation would need to take several types of costs into account. One source of costs that has received most attention is problems associated with asymmetric and incomplete information. Another source is the fact that regulation takes place in an institutional environment that imposes certain feasibility constraints (e.g., certain procedural and majority requirements) and hence costs of changing existing arrangements. 
Taken together, these arguments suggest that much of current regulatory theory and practice must be considered as a special case of a more general approach to governing a dynamic adaptive system. We will explore the implications of this insight for a forward-looking European approach in the next section.

\section{A REASSESSMENT OF EUROPEAN ELECTRON- IC COMMUNICATIONS POLICY}

In the light of the previous sections the European experience can be reassessed and reconstructed. A nuanced interpretation requires looking at the national and European levels. The overall reform process has contributed to remarkable improvements in sector performance since the 1980s as measured in diffusion rates of advanced ICT and other achievements of the sector. By the 1970s, there was a widespread sense that the state monopoly model had run its course and could not be reformed to meet the needs of users under the conditions of rapidly evolving technology. The blueprint adopted by the EU of liberalization and independent regulation allowed realizing great efficiency gains and unleashed innovation. Likewise, the application of traditional regulatory theory and practices facilitated the entrance of new players in fixed networks. Unbundling policies, adopted beginning in 1999, bolstered the diffusion of first generation broadband services, based mostly on the network of incumbent service providers. The combination of independent regulation and industrial policy bore unanticipated fruits, especially in digital mobile communications, where the GSM system advanced to a global standard. European authorities and NRAs measured their success largely by the increases in adoption and the decreases in consumer prices. For many years steady performance improvements could be achieved by this combination of policies.

However, as the sector further evolved, new unanticipated challenges arose. The roots of many of these issues can be found in forms of path dependence (Belloc et al., 2013; J. Cave, 2009). During the early days of mobile communications the EU member states insisted that spectrum management remain a national issue. Although this was workable for $2 \mathrm{G}$ mobile, it arguably turned into a disadvantage in the transition to $3 \mathrm{G}$ mobile services, where licenses were awarded in spectrum auctions. One unanticipated side effect was the pursuit of national licensing timetables and approaches rather than regional or even pan-European approaches. On the one hand, this led initially to astronomical prices paid for spectrum. While later auctions did not achieve similarly high prices, the financial burden, contrary to what some mainstream economists argued, delayed the introduction of $3 \mathrm{G}$ mobile and later $4 \mathrm{G}$ 
mobile. Another repercussion of the success of GSM was that it seems to have shaped expectations that the same model could be applied to the next generation of mobile Internet services. Alas, 3G was based on a very different value network of players, requiring more than an integrating technical standard (UMTS. The coordination among the players did not come forth in the European (or the US) market for a long time, giving Japan and South Korea an opportunity to move ahead.

A similar negative effect of earlier decisions affected the further evolution of fixed broadband markets. The prolongation of ex ante regulation in advanced broadband eventually also was written into the European framework for next-generation networks, although in a somewhat weakened form (M. E. Cave \& Shortall, 2011; EC, 2010). During prolonged negotiations, stakeholder positions hardened and became increasingly irreconcilable. New entrants, represented by the European Competitive Telecommunications Association (ECTA) lobbied for continued policies that favored their members and the association of incumbent players, the European Telecommunications Network Operator Association (ETNO) for relaxed forms of regulation. The latter position was that overly stringent regulation, contributing to low consumer prices and easy entry for competitors, had thus suppressed the incentive to invest in next-generation networks. ECTA and its consultants argued that the economies of scale for next-generation networks would only supply one or a few dominant suppliers in all but the largest urban markets. Both positions contain a kernel of truth but both are also heavily influenced by the strategic positions of the stakeholders. In the end, by the time the EU adopted a compromise policy, the window of opportunity to allow more competitive market organization in next-generation networks was closed.

The lack of investment in next-generation network infrastructure continues to be a serious problem in many of its member states. The European Investment Bank estimates that achieving universal deployment of high-speed networks that support download speeds of 50-100 mpbs would require investment expenses of about Euro 250-280 billion (Gruber, 2010). At the current pace of market-driven investment, the EU is not likely to reach this goal by private sector investment. There are several paths forward: 1) reliance on public sector investment, 2) public-private partnerships, (3) new forms of universal service programs, (4) relaxed regulation and rejuvenation of market forces, and (5) combinations of 1)-(4. Given the state of public finances, it is unlikely that the gap left by private investment can be closed by public initiatives alone. Although public-private partnerships have worked in limited circumstances, there is a long track record of projects that failed at the expense of tax payers, so that this may not be a panacea to overcome the investment shortfall (Melody, 2013). Policies in this realm also have to be compatible with the European regulations for state aid. Often, these regulations constrain innovative public sector policy interventions (Gomez-Barroso \& Feijoo, 2012). A third option would be to devise universal service programs in which limited public sector fund- 
ing and subsidies are leveraged to improve the viability of private investment. Thus far, the EU has been reluctant to introduce broadband universal service measures, in part because one of its self-imposed preconditions for such programs is that a service has been adopted widely (Bohlin \& Teppayayon, 2009). This approach does, to some degree backfire in situations where the goal is to accelerate network deployment and not just to fix limited forms of market failure.

A fourth strategy is to adapt the regulatory framework to reenergize competitive forces. There are several options how this can be done, some with less and some with more government prodding. An approach inspired by limited government intervention would be to relax regulations that potentially depress investment and innovation to promote risk taking by private entrepreneurs. This could be achieved with a combination of relaxed access and price regulation (e.g., for termination) combined with a policy of making access to civil engineering infrastructure more easily available Compared to the status quo ante, this alternative would likely create winners and losers both on the supply and demand side and would face strong political resistance. However, given the technological and market dynamics of the ICT sector, this may be an attractive option going forward. It would also require regulators to be comfortable with letting go of a slew of controls and detailed regulations that are currently in place. As such measures would likely result in restructuring of prices, both by adding more expensive and less expensive user options, this policy might also generate concerns about consumer welfare and some backlash from users, even though it might be welfare enhancing overall (Bauer \& Wildman, 2012). A policy of less regulation may have the undesirable side-effect that open network architectures that drove the Internet may be replaced by private IP network environments that allow better configuration of quality of service and price differentiation but also generate additional transaction costs for independent third parties (Claffy \& Clark, 2013).

Competitive forces could also be stimulated with policies that rely more strongly on government intervention. These are squarely in the tradition of pro-competitive regulation that has dominated past European policy design. In that sense, they are more compatible with existing practices but they also share many of the shortcomings discussed in section three. One model that has been implemented in a few countries is structural separation between the network and services (e.g., Open Reach in the UK) or forms of functional separation (e.g. in Sweden) (Teppayayon \& Bohlin, 2011). These options are feasible as long as certain incentive problems are overcome. One challenge is the design of the economic incentives to deploy networks. Here, some form of regulated pricing and earnings, despite the critique that led to the demise of these forms of regulation, would allow aligning the incentives of investors and users. Moreover, it would be possible to impose a universal service and common carriage mandate on networks within a framework of coherent economic incentives. A second challenge is the coordination between the players in higher layers and the providers of network infrastructure. As advanced communication servic- 
es are becoming more complex, it may be increasingly difficult to orchestrate such coordination through markets (M. E. Cave, 2006). This can lead to a mismatch between the needs of application and service providers and investors in network services. Vertical integration can help mitigate these incentive issues so that there is a trade-off between the clarity of the regulatory system and allowing conditions that support dynamic innovation and investment dynamics of advanced communications.

Not all member states experienced a similar fate, though. Countries such as Sweden, the Netherlands, and Denmark with high problem solving capacity were able to design innovative programs of public-private sector collaboration, often including municipalities that boosted rolling out fiber networks. Although not an EU member, Switzerland allowed collaboration between local utilities and Swisscom in the deployment of local access networks, elevating its broadband penetration to reach a global leadership position (OECD, 2013). Other countries, such as Austria, benefited from the presence of an aggressive competitor with an ambitious mobile broadband deployment strategy. These are all signs of the working of the ICT ecosystem and the ability of innovative solutions or of competition to emerge in unexpected places. Such national success stories suggest that the EU would be well-advised to allow more national experimentation as a regional learning process can be set in motion. As discussed above, from an evolutionary institutional perspective, some level of diversity and heterogeneity may be desirable, although it has to be traded off against increased transaction costs of differentiated regulatory regimes.

This leads to one of the persistent puzzles of European electronic communications reform. Despite decades of regional coordination and integration, no integrated European communications market emerged. One of the goals of the reforms during the 1980s, to overcome the "patchwork Europe", remains as relevant today as part of the Digital Agenda 2020. Looking back it is possible to identify several factors at play. One is the cultural and political heterogeneity of Europe that requires targeting a business strategy to national and sub-national markets. The continued national organization is reinforced by different national sector organization ranging from powerful national monopolies in Germany and France to more decentralized organization in Spain and Italy. These factors contributed to the establishment of a regulatory system with a strong role for national regulatory authorities. Even though European rules homogenize and synchronized national rules, the presence of 28 NRAs adds a strong spatial structure to markets. Even small initial deviations in regulatory approaches and timelines of reform will provide an additional reason for suppliers to look at each national market separately. This has been particularly visible in the area of spectrum management, rules for rights of way management, and the willingness to adopt universal broadband service policies. Establishment of a European regulatory agency could have counteracted some of these trends but was rejected several times. Last but not least, the continued interest of the state as part-owner and operator in some countries combined with strong sentiments in favor of national 
control of critical infrastructures have undermined a process of European industry consolidation that might have helped overcome national fragmentation. The paucity of pan-European service providers is particularly detrimental to businesses looking for one-stop shopping for their communication needs (Godlovitch, Monti, Schäfer, \& Stumpf, 2013).

\section{CONCLUDING REMARKS}

European electronic communications reform can best be understood by analyzing the interplay of national and European levels. A handful of European nations, including Sweden, Finland, and Denmark, have historically been among the top performers in the world. As a an economic region, the member states of the European Union, either delineated as the EU-15 or the enlarged EU-28, historically lagged behind international peer regions, especially the US (and during the past decades a few leading Asian countries. However, within less than a dozen years, beginning in the late 1980s, European electronic communications was radically transformed from nearly a century of state monopoly to an environment of regulated competition. In the course of these reforms, the region was able to close the historical performance deficit that had prevailed for much of the twentieth century. The adopted model of liberalization combined with independent sector regulation was an appropriate response to the technological and economic conditions of the industry as well as the political conditions at the time. It facilitated rapid diffusion of services, entrants of new players and the associated innovations, and declining process, all integrated in a virtuous cycle of efficiency gains and growth.

After 25 years of reforms, several new challenges need to be confronted. Some are beyond the control of national and European policy makers. Fundamental shifts in global value generation have shifted important economic activities to low and middle-income countries. Advanced ICT has facilitated these shifts and hence increased the pressure to develop employment opportunities in high-tech industries heavily reliant on advanced communications. At the same time, these technologies offer a highly plastic and malleable production technology in which products and services can be generated with multiple alternative processes (e.g., video service can be configured via cable TV, satellite, P2P streaming, content delivery networks-CDNs, etc.), generating enormous competitive pressure and tumultuous market conditions in which sustained and high investment in infrastructure networks is difficult to sustain. Many of the digital technologies also allow a high rate of substitution of human capital by machine capital, thus creating significant strain on jobs and employment. Moreover, they go hand in hand with a process of de-monetization of services and a severe 
redistribution of income to technologically savvy risk takers. European policy, like policy elsewhere, will have to find new responses to these challenges but it is difficult to see how the big agendas (e.g., the Digital Agenda 2020 or the American Agenda for American Innovation) can be effective responses to these global tidal forces.

Other challenges originate in the need to adapt the existing framework to the new economics and technological conditions within the ICT sector. Here the European framework has, at least in some areas, turned into a legacy that is in the way of the massive network investment needed in the coming decade. In an international comparison, such periods of transition between an old regime of regulation and a new one are visible periodically and they need to be expected. As the EU seeks for innovative solutions going forward, it will be important to design regulatory frameworks and practices that are more attuned with the dynamic adaptive system characteristics of advanced communication systems. 


\section{REFERENCES}

Aghion, P., N. Bloom, R. Blundell, R. Griffith, and P. Howitt. 2005. Competition and Innovation: An Inverted-U Relationship. Quarterly Journal of Economics, 120: 701-728.

Armstrong, M. 2006. Competition in Two-sided Markets. RAND Journal of Economics, 37 (3): 668-691.

Atkinson, R. D., and S. Ezell. 2012. Innovation Economics. New Haven, CT: Yale University Press.

Ballon, P., and E. Heesvelde. 2011. ICT platforms and regulatory concerns in Europe. Telecommunications Policy, 35 (8): 702-714.

Bance, P. 2007. Liberalization of European Telecommunications: Sectoral Dynamics and Structural Mutations. Annals of Public and Cooperative Economics, 78 (3): 331-351.

Bauer, J. M. 2003. Public Utilities in the Perspective of the Gemeinwirtschaftslehre. In E. S. Miller and W. J. Samuels (Eds.). An Institutionalist Approach to Public Utilities Regulation. East Lansing, MI: Michigan State University Press.

Bauer, J. M. 2005. Regulation and State Ownership: Conflicts and Complementarities in EU Telecommunications. Annals of Public and Cooperative Economics, 76 (2): 151-177.

Bauer, J. M. 2008. Balancing Regulation, Investment, and Innovation: EU and US Approaches to NGN. Paper presented at the Biannual Conference of the International Telecommunications Society, Montreal, Canada.

Bauer, J. M. 2010a. Learning from Each Other: Promises and Pitfalls of Benchmarking in Communications Policy. Info, 12 (6): 8-20.

Bauer, J. M. 2010b. Regulation, Public Policy, and Investment in Communications Infrastructure. Telecommunications Policy, 34 (1-2): 65-79.

Bauer, J. M. 2013. Platforms, Systems Competition, and Innovation: Reassessing the Foundations of Communications Policy. Unpublished manuscript, Michigan State University, East Lansing, MI.

Bauer, J. M., and S.S. Wildman. 2012. The Economics of Usage-Based Pricing in Broadband Markets. Available at http://i.ncta.com/ncta com/PDFs/Wildmanreport web.pdf.

Baumgartner, F. R., and B. D. Jones. 1993. Agendas and Instability in American Politics. Chicago, IL: University of Chicago Press.

Becker, G. S. 1983. A Theory of Competition Among Pressure Groups for Political Influence. Quarterly Journal of Economics, 98 (3): 371-400.

Bell, D. 1973. The Coming of Post-industrial Society: A Venture in Social Forecasting. New York: Basic Books.

Belloc, F., A. Nicita and P.L. Parcu. 2013. Liberalizing telecommunications in Europe: path dependency and institutional complementarities. European Journal of Public Policy, 20 (1): 132-154. doi: 10.1080/13501763.2012.693409.

Belloc, F., A. Nicita and M.A. Rossi. 2012. Whither Policy Design for Broadband Penetration? Evidence from 30 OECD Countries. Telecommunications Policy, 36 (5): 382-398.

Bennett, R., L.E. Stewart and R.D. Atkinson. 2013. The Whole Picture: Where America's Broadband Networks Really Stand. Washington, DC: The Information Technology \& Innovation Foundation. 
Berg, S. V. and J. Tschirhart. 1988. Natural Monopoly Regulation: Principles and Practice. Cambridge: Cambridge University Press.

Bohlin, E. and O. Teppayayon. 2009. Broadband universal service: A future path for Europe? International Journal of Management and Network Economics, 1 (3).

Bös, D. 1981. Economic Theory of Public Enterprise. Berlin and New York: Springer.

Bourreau, M., C. Cambini, C. and S. Hoernig. 2012. Ex ante Regulation and Co-investment in the Transition to Next Generation Access. Telecommunications Policy, 36 (5): 399-406.

Bozeman, B. 2007. Public Values and Public Interest: Counterbalancing Economic Individualism. Washington, DC: Georgetown University Press.

Bunge, M. 1979. A Systems Concept of Society: Beyond Individualism and Holism. Theory and Decision, 10: 13-30.

Cambini, C. and V. Silvestri. 2012. Technology Investment and Alternative Regulatory Regimes with Demand Uncertainty. Information Economics and Policy, 24 (3-4): 212-230.

Cave, J. 2009. Prisoners of Our Own Device - An Evolutionary Perspective on Lockin, Technology Clusters and Telecom Regulation. Paper presented at the 37th Research Conference on Communications, Information, and Internet Policy, Arlington, VA.

Cave, M. E. 2006. Six Degrees of Separation: Operational Separation as a Remedy in European Telecommunications Regulation. Communications and Strategies, 64: 89-103.

Cave, M. E. and T. Shortall. 2011. The Extended Gestation and Birth of the European Commission's Recommendation on the Regulation of Fibre Networks. Info, 13 (5): 3-18.

Cave, M. E. and T. Valletti. 2000. Regulation and Competition in Telecommunications. In G. Galli and J. Pelkmans (Eds.). Regulatory Reform and Competitiveness in Europe, 2: Vertical Issues. Cheltenham, UK and Northampton, MA: Edward Elgar.

Cherry, B. A. 2007. Telecommunications Economy and Regulation as Coevolving Complex Adaptive Systems: Implications for Federalism. Federal Communications Law Journal, 59: 369-402.

Cherry, B. A. and J.M. Bauer. 2004. Adaptive regulation: contours of a policy model for the Internet economy. Quello Center Working Paper 04-05, East Lansing, $\mathrm{Ml}$ : Michigan State University.

Claffy, K. C. and D.D. Clark. 2013. Platform Models for Sustainable Internet Regulation. Available at SSRN: http://ssrn.com/abstract=2242600.

Cowhey, P. F. and J.D. Aronson. 2009. Transforming global information and communication markets: the political economy of innovation. Cambridge, MA; London: MIT Press.

de Streel, A. 2003. Market Definitions in the New European Regulatory Framework for Electronic Communications. Info, 5 (3): 27-47.

de Streel, A. 2008. Current and Future European Regulation of Electronic Communications: A Critical Assessment. Telecommunications Policy, 32 (11): 722-734.

Easley, D. and J. Kleinberg. 2010. Networks, Crowds, and Markets: Reasoning About a Highly Connected World. Cambridge: Cambridge University Press.

EC. 1987. Green paper on the development of the Common Market for telecommunications services and equipment. Brussels: Commission of the European Communities, Directorate-General for Telecommunications, Information Industries, and Innovation. 
EC. 1997. Green Paper on the Convergence of the Telecommunications, Media and Information Technology Sectors, and the Implications for Regulation. COM(97)623. Brussels, 3 December 1997.

EC. 2002. Commission guidelines on market analysis and the assessment of significant market power under the Community regulatory framework for electronic communications networks and services. Official Journal of the European Union, C 165: 6-31.

EC. 2003. Commission recommendation on relevant product and service markets within the electronic communications sector susceptible to ex ante regulation. Official Journal of the European Union, L 114: 45-49.

EC. 2007. Commission recommendation on relevant product and service markets within the electronic communications susceptible to ex ante regulation. Official Journal of the European Union, L 344: 65-69.

EC. 2010. Commission Recommendation of 20 September 2010 on Regulated Access to Next Generation Access Networks (NGA), 2010/572/EU. Brussels: Commission of the European Communities.

EC. 2013. Green Paper Preparing for a Fully Converged Audiovisual World: Growth, Creation and Values. COM2013) 231 final. Brussels, 24 April 2013.

Edwards, G. and L. Waverman. 2006. The Effects of Public Ownership and Independence on Regulatory Outcomes. Journal of Regulatory Economics, 29 (1): 23-67.

Eliassen, K. A. and M. Sjovaag (Eds). 1999. European Telecommunications Liberalisation (Vol. 10). London, New York: Routledge.

Evans, D. S. 2012. Two-Sided Markets. In ABA Section of Antitrust Law (Ed.). Market Definition in Antitrust Theory and Case Studies. Washington, DC: American Bar Association.

Falch, M. and A. Henten. 2010. Public-private Partnerships as a Tool for Stimulating Investments in Broadband. Telecommunications Policy, 34 (9): 496-504.

Falch, M., A. Henten and K.Vandrup. 2010. Mobile Internet Developments in Europe, East Asia, and the US. In A. Gentzoglanis and A. Henten (Eds). Regulation and the Evolution of the Global Telecommunications Industry. Cheltenham, UK; Northampton, MA: Edward Elgar.

Foreman-Peck, J. and J. Müller. 1988. European Telecommunications Organisations. Baden-Baden: Nomos Verlagsgesellschaft.

Fransman, M. 2002. Telecoms in the Internet Age. Oxford: Oxford University Press.

Fransman, M. 2007. Innovation in the New ICT Ecosystem. Communications and Strategies, 68 (4th quarter): 89-110.

Fransman, M. 2010. The New ICT Ecosystem: Implications for Policy and Regulation. Cambridge, UK: Cambridge University Press.

Frischmann, B. M. 2012. Infrastructure: The Social Value of Shared Resources. New York: Oxford University Press.

Gawer, A. and M.A. Cusumano. 2002. Platform Leadership: How Intel, Microsoft, and Cisco Drive Industry Innovation. Boston, MA: Harvard Business School Press.

Godlovitch, I., A. Monti, R.G. Schäfer and U. Stumpf. 2013. Business Communications, Economic Growth and the Competitive Challenge. Study for the European Competitive Telecommunications Association (ECTA) and the International Telecommunications User Group (INTUG. Bad Honnef, Germany: WIK-Consult GmbH.

Goldberg, V. P. 1976. Regulation and Administered Contracts. Bell Journal of Economics, 7 (2): 426-452. 
Gomez-Barroso, J. L. and C. Feijoo. 2012. Volition versus Feasibility: State Aid When Aid Is Looked Upon Favourably: The Broadband Example. European Journal of Law and Economics, 34 (2): 347-364.

Greenstein, S. 2011. The Direction of Broadband Spillovers. Micro, IEEE, 31 (2).

Greenstein, S. and T. Khanna. 1997. What Does Industry Convergence Mean? In D. B. Yoffie (Ed.). Competition in the Age of Digital Convergence. Boston: Harvard Business School Press.

Gruber, H. 2010. European Sector Regulation and Investment Incentives for Broadband Communication Networks. In M. Falch and J. Markendahl (Eds.). Promoting New Telecom Infrastructures: Markets, Policies and Pricing. Cheltenham, UK; Northampton, MA: Edward Elgar.

Hagiu, A. and J. Wright,. 2011. Multi-sided Platforms. Working Paper 12-024, Harvard Business School.

Hayek, F. A. 1968. Der Wettbewerb als Entdeckungsverfahren. Kieler Vorträge gehalten im Institute für Weltwirtschaft an der Universität Kiel, Neue Folge 56. Kiel, Germany.

Hayek, F. A. 2002. Competition as a discovery procedure (translated by Marcellus S. Snow). The Quarterly Journal of Austrian Economics, 5 (3): 9-23.

Hogendorn, C. 2012. Spillovers and Network Neutrality. In G. Faulhaber, G. Madden and J. Petchey (Eds.). Regulation and the Performance of Communication and Information Networks. Cheltenham, UK; Northampton, MA: Edward Elgar.

Jordana, J. (Ed). 2002. Governing Telecommunications and the New Information Society in Europe. Cheltenham, UK: Edward Elgar.

Joskow, P. and R. Noll. 1981. Regulation in Theory and Practice: An Overview. In G. Fromm (Ed.). Studie in public regulation. Cambridge, MA: MIT Press.

Kahn, A. E. 1970/71. The Economics of Regulation: Principles and Institutions. New York: Wiley.

Kiessling, T. and Y. Blondeel. 1998. The EU regulatory framework in telecommunications: A critical analysis. Telecommunicaitons Journal, 22 (7).

Laffont, J.-J. and J. Tirole. 2000. Competition in Telecommunications. Cambridge, MA: MIT Press.

Latzer, M. 1997. Mediamatik: Die Konvergenz von Telekommunikation, Computer und Rundfunk. Opladen: Westdeutscher Verlag.

Majone, G. 1991. Cross-National Sources of Regulatory Policy Making in Europe and the United States. Journal of Public Policy, 11: 79-106.

Majone, G. 1996a. The Rise of Statutory Regulation in Europe. In G. Majone (Ed.). Regulating Europe. London; New York: Routledge.

Majone, G. 2001. Nonmajoritarian Institutions and the Limits of Democratic Governance: A Political Transaction-cost Approach. Journal of Institutional and Theoretical Economics, 157: 57-78.

Majone, G. (Ed). 1996b. Regulating Europe. London; New York: Routledge.

Marcus, J. S. 2003. The Potential Relevance to the United States of the European Union's Newly Adopted Regulatory Framework for Telecommunications. In L. F. Cranor and S. S. Wildman (Eds.). Rethinking Rights and Regulations: Institutional Responses to New Communication Technologies. Cambridge, MA: MIT Press.

Marcus, J. S. 2005. Is the U.S. Dancing to a Different Drummer? Communications \& Strategies, 60: 39-58.

Martimort, D. 1999. The Life Cycle of Regulatory Agencies: Dynamic Capture and Transaction Costs. Review of Economic Studies, 66 (4): 929-947. 
Melody, W. H. 2013. Moving beyond liberalization: stumbling toward a new European ICT policy framework. Info, 15 (2): 25-38.

Michalis, M. 2006. European Governance: Communications. From Unification to Coordination. Lexington Books. Lanham, MD.

Noam, E. M. 1992. Telecommunications in Europe. New York: Oxford University Press.

Nora, S. and A. Minc. 1978. L'informatisation de la Societe. Paris: La Documentation Francaise.

Nowotny, E. 1982. Nationalized Industries as an Instrument of Stabilization Policy: The Case of Austria. Annals of Public and Co-operative Economy, 53 (1): 41-57.

OECD. 2011. Communications Outlook 2011. Paris: Organisation for Economic Co-operation and Development.

OECD. 2013. Communications Outlook 2013. Paris: Organisation for Economic Co-operation and Development.

Owen, B. M. and R. Braeutigam. 1978. The regulation game: strategic use of the administrative process. Cambridge, MA: Ballinger.

Peltzman, S. 1976. Toward a More General Theory of Regulation. Journal of Law and Economics, 19 (2): 211-240.

Phillips, C. F., Jr. 1993. The Regulation of Public Utilities: Theory and Practice. Arlington, VA: Public Utilities Reports, Inc.

Rochet, J.-C. and J. Tirole. 2003. Platform Competition in Two-Sided Markets. Journal of the European Economic Association, 1 (4): 990-1029.

Rysman, M. 2009. The Economics of Two-Sided Markets. Journal of Economic Perspectives, 23 (3): 125-143.

Sabel, C. F. and J. Zeitlin. (Eds). 2010. Experimentalist Governance in the European Union: Towards a New Architecture. Oxford: Oxford University Press.

Serentschy, G. 2013. The Virtuous Circle: New Regulations, Innovation and Investment: How to bring Europe back to the Top. Vienna, Austria: RTR-Rundfunk \& Telekom Regulierungs $\mathrm{GmbH}$.

Spulber, D. F. 1989. Regulation and Markets. Cambridge, MA: MIT Press.

Spulber, D. F. 2006. Firms and Networks in Two-Sided Markets. In T. Hendershott (Ed.). Economics and Information Systems. Amsterdam: Elsevier.

Stigler, G. J. 1971. The Economic Theory of Regulation. Bell Journal of Economics and Management Science, 2: 3-21.

Teppayayon, O. and E. Bohlin. 2011. Functional Separation in Swedish Broadband Market: Next Step of Improving Competition. Telecommunications Policy, 34 (7): 375-383.

Teske, P. E. 1990. After divestiture: the political economy of state telecommunications regulation. Albany, N.Y.: State University of New York Press.

Teske, P. E. (Ed). 1995. American Regulatory Federalism and Telecommunications Infrastructure. Hillsdale, N.J.: Lawrence Erlbaum Associates.

Thatcher, M. 1999. The Politics of Telecommunications. Oxford: Oxford University Press.

Thatcher, M. 2002. The relationship between national and European regulation of telecommunications. In J. Jordana (Ed.). Governing Telecommunications and the New Information Society in Europe. Cheltenham, UK; Northampton, MA: Edward Elgar.

Thiemeyer, T. 1983. Deregulation in the Perspective of the German "Gemeinwirtschaftslehre". Journal of Institutional and Theoretical Economics, 139: 405-418.

Tintor, V., M. Jankovic and V. Milicevic. 2010. The Legal and Economic Framework of EU Telecom Market Regulation. Economic Annals, LV (185): 107-128.

Toffler, A. 1980. The Third Wave. New York: Morrow. 
Train, K. E. 1991. Optimal Regulation: The Economic Theory of Natural Monopoly. Cambridge, MA: MIT Press.

Tsebelis, G. 2002. Veto Players: How Political Institutions Work. Princeton, NJ: Princeton University Press.

Ungerer, H. 1988. Telecommunications in Europe: Free Choice for the User in Europe's 1992 Market. Brussels: Commission of the European Communities.

Vogelsang, I. 2003. Cross-Fertilization between U.S. and European Telecommunications Regulation. In G. Illing and U. Kluh (Eds.). Spectrum Auctions and Competition in Telecommunications. Cambridge and London: MIT Press.

Wallsten, S. J. 2008. Understanding International Broadband Comparisons. Washington, DC: Technology Policy Institute, available at SSRN: http://ssrn.com/abstract=1136831.

West, J. and M. Mace. 2010. Browsing as the Killer App: Explaining the Rapid Success of Apple's iPhone. Telecommunications Policy, 34 (5-6): 270-286.

Whitt, R. S. and S. Schultze. 2009. The New 'Emergence Economics' of Innovation and Growth, and What it Means for Communications Policy. Journal of Telecommunications and High Technology Law, 7: 217-315.

Wilson, J. Q. (Ed). 1980. The Politics of Regulation. New York: Basic Books.

Zenhäusern, P. and Y. Schneider. 2012. Polynomics Telecommunication Regulation Index 2012. Paper presented at the 23rd European Regional Conference of the International Telecommunications Society, Vienna, Austria.

Zenhäusern, P., Y. Schneider, S. Berner and S. Vaterlaus. 2012. Polynomics Regulation Index 2012. Olten, Switzerland: Polynomics. 